\title{
ON THE TREATMENT OF ENL WITH INTRAVENOUS INJECTION OF A LARGE QUANTITY OF VITAMIN C.
}

\author{
Toshio INABA, Tsunehiro KAWAWAKI \& Suematsu ISHIKAWA \\ National Suruga Sanatorium
}

\begin{abstract}
Regarding the effectiveness of the treatment of ENL (Erythema nodosum leprosum) with Vitamin C (1-ascorbic acid) injection, one of the authors had presented a paper at the 14th Japanese Leprosy Conference in 1940.

The present authors studied again on the same subject with a large dose of the preparation which was administered intravenously with considerable good effects. The results are summarized as follows :
\end{abstract}

1. The number of leprosy cases with ENL under this treatment amounted to 11 (male 5, female 6).

2. The preparation of Vitamin $\mathrm{C}$ employed was Vitacimin (TAKEDA) : 1cc. (100mg) and 2cc. (500mg) of 1-ascorbic acid solution in each ampule for intravenous use.

3. The administration of the drug was repeated every day as a daily dose of $100 \mathrm{mg}, 200 \mathrm{mg}$ or $500 \mathrm{mg}$.

4. The total effectivity rate was $73 \%(8 / 11)$.

5. Discolouration of the erythema occurred in 2 to 6 days (4 days on an average), the total amount of ascorbic acid administered being 200 to $3000 \mathrm{mg}$ ( $1328 \mathrm{mg}$ on an average).

6. Complete disappearance of the erythema was seen in 4 to 15 days (10 days on an average), the amount of ascorbic acid injected being 660 to $7500 \mathrm{mg}$ ( $3120 \mathrm{mg}$ on an average).

7. No side effects were encountered. Furthermore, even in a case with ENL, which brought about mental disorder following cortisone treatment, the Vitamin $\mathrm{C}$ therapy was well tolerated and gave a remarkably favorable effect in the treatment of ENL.

\section{らい性結節性紅斑のビタミンC大量静注療法}

\section{*稻萻捘雄・川脇常弘・石河末松}

らいのL型（らい腫型）の治療経過中に, アレルギー

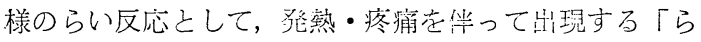
い性結節性紅斑」は，らい治療上き方わて重要な併癷症 の 1 つである。

このらい性結節性紅斑に対するビタミンC療法（ビタ シミン注射液を使用)の効果については,著者の 1 人嫍葉 が,すでに1940年(㖊和15年)に符14回日本らい学会に, 1942年（炤和17年）に笨17回日本瀨学会に，また1942年 （昭和17年）臨將医報No.617亿発表し46名中38名(79.0

\footnotetext{
* 国立駿河療養所 （1961年12月20日受稿）
}

\%）に有効であるとと圭報告した。そのときの薬剂はビ タシミン (武时) $2.0 \mathrm{cc}$ (100mg) で, 每日南るいは䧣日 に皮下注射した。

近来, 国立弘前病院の徳永氏は, 急性湿疹その他のア レルギー性皮伖疾患に対して，ビタミンCの大量静注尞 法を行い，45例中40例（88.9\%）に有効であると報告し ている。

著者らは，このビタミンC大量静注療法を，らいにお けるアレルギー様の併発症である「らい性結節性紅斑」に 対して実施してみたところ，所期の如く有効であった。 (11例中8例，72.7\%)。またV C 療法の副作用は皆涠で 
あったから，副作用のために，この站斑に有効なコーチ ゾン療法を続行できない症例にも，このVC療法は安心 して使用できることを知ったので，ここに炤和 34 年日本 らい学会東部地方会にて演説した成績を記載しておく。

\section{使用 方法}

注射液はビタシミン「タケダ」注射液 $1 \mathrm{cc}$ (1-アスコ ルビン酸 $100 \mathrm{mg}$ 含付) と $2 \mathrm{cc}$ (500mg 含有) のアンプー ルの単独使用で, 1 回使用䀶は $100 \mathrm{mg}, 200 \mathrm{mg}$ あるい は500mgで，毎日 1 回时静脈内に注射した。

症例は11例で，急性型ないし亜急性型のらい性結節性 ·紅斑の患者である。
間の使用 V C 総量は最少 $600 \mathrm{mg}$, 最大 $7500 \mathrm{mg}$ で, 吸卭 までの平均使用総量は $3120 \mathrm{mg}$ であった。

次に熱型について述べると, 概放最高 $38^{\circ} \sim 39^{\circ} \mathrm{C}$ の 発熱を伴い弛張熱あるいは䅮留熱の形を示していたが， V C 投与により紅斑の遈色と平行して渙散性またときに は分利性に解熱した。

興味ある1例は症例 8 で，22才の女子，精神分裂病的 傾向古る患者で, 紅斑は全身に中等度に多発し, 当初乙 の紅斑治療のため現在最も有効上認められている cotisone を投与したところ，4 日目に発熱はなお稽留性で $38^{\circ} \sim 39^{\circ}$ の問にあり，紅斑も依然として退色せず，その うえに幻覚，妄想を認わるに至ったので， cortisone 投

成 績一覧 表

\begin{tabular}{|c|c|c|c|c|c|c|c|c|c|c|}
\hline 症 例 & 性 & 年 令 & $\begin{array}{l}\text { 新 斑 } \\
\text { 程 度 }\end{array}$ & 部 位 & $\begin{array}{c}1 \text { 回量 } \\
\mathrm{mg}\end{array}$ & $\begin{array}{l}\text { 全注射 } \\
\text { 回 数 }\end{array}$ & $\begin{array}{l}\text { 総 量 } \\
\text { mg }\end{array}$ & $\begin{array}{l}\text { 退色まで } \\
\text { 回 数 }\end{array}$ & $\begin{array}{l}\text { 吸収まで } \\
\text { 回 数 }\end{array}$ & 判 定 \\
\hline 1 & $\hat{o}$ & 17 & 中 & $\begin{array}{l}\text { 両下腿 } \\
\text { 㮍前肪 }\end{array}$ & 500 & 15 & 7500 & 6 & 15 & 疗効 \\
\hline 2 & $\hat{o}$ & 41 & 中 & 全身所ヶ & 500 & 6 & 3000 & 2 & 6 & 䏍 效 \\
\hline 3 & 우 & 64 & 中 & 同上 & 500 & 9 & 4500 & 6 & 9 & 有 效 \\
\hline 4 & $\widehat{8}$ & 37 & 塾 & 顔・四肢 & 100 & 7 & 700 & 4 & 7 & 行 効 \\
\hline 5 & 今 & 44 & 中 & 同上 & 100 & 6 & 600 & 2 & 6 & 花 効 \\
\hline 6 & 우 & 33 & 鼔 & 両四肢 & 500 & 13 & 6500 & 不明 & 13 & 有 效 \\
\hline 7 & 우 & 48 & 軽 & 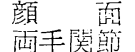 & 200 & 4 & 800 & 2 & 4 & 有 效 \\
\hline 8 & 우 & 22 & 中 & 顏面四肢 & 100 & 10 & 1000 & 3 & 10 & 有 効 \\
\hline 9 & $\hat{o}$ & 59 & 軽 & 同上 & 200 & 25 & 5000 & 15 & 25 & 無 效 \\
\hline 10 & 우 & 60 & 鲴 & 顔 面 & 200 & 20 & 4000 & - & - & 搮 効 \\
\hline 11 & 우 & 39 & 䨝 & 全身所々 & 500 & 16 & 8000 & - & - & 無 効 \\
\hline
\end{tabular}

\section{成 續}

効果の判定は皮疹の紅斑の退色・吸仅までの日数之全 身発熱 $\left(38^{\circ} \sim 39^{\circ} \mathrm{C}\right.$, 弛張性之恙に!留性) の解熱の 状況を目標として行った。つぎに注射回数・1-アスコル ビン酸投与総量・紅斑退色およで吸收までの注射回数・ 効果判定などを表示する。

静注 1 回量は $100 \mathrm{mg} 3$ 名, 200mg 3名, 560mg 5名 で，全注射回数は 4〜25回之区々であったが，一空15回 以上注射して紅斑の退色を見ない症例は無効とした。有 効率は72.7\% $(8 / 11)$ で, 無効は 3 例で, それらはそれぞ れ心臟性喘息, 肺結核兼膿胸, 回虫症を合併していた。 有効例 8 名について見ると, 紅斑退色までの最短使用 日数は 2 日で, 最長は 6 日で, 平均 4 日で退色に至っ た。また，その閒の使用 VC 総量は最少 $200 \mathrm{mg}$, 最大 $3000 \mathrm{mg}$ で, 退色までの平均総量は $1186 \mathrm{mg}$ であった。 次に紅斑吸収までの最短使用日数は 4 日で, 最長は15日 で，平均10日で紅斑吸収に至ること在知った。またその

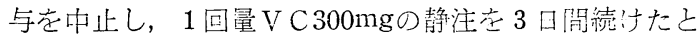
ころ，3 日目に分利性の解熱あり，また紅斑の著明な漫 色を見た。その後 V C 静注 ( 1 回 $300 \mathrm{mg}$ ) を続行し, 10 日にして紅斑の完全な吸收消失を見，幻賞，妄想与同洔 に消失した。

\section{考察}

らい性結節性紅斑のビタミンC療法の有効性につい て，著者は1940年(昭和15年)に日本癩”学会に発表した。 この研究は1940年に International Journal of Leprosy Vol.8亿抄録さ机た論文「Ugarriza, R.G.：癩性敗血症 とツェビオン (Cebion)」にヒントを得て始めたものだ ある。大風子油療法中に起った 3 力月屯続く敗血症性発 熱に対して, Cebion (メルク製ビタミンC剂)の錠剂を 投与し，3 日にして解熱し患者の症状は回復した 1 例の 報告に興味をむち，この患者の症状はわれわれの云うら い性結節性紅斑に外ならぬもの之推定して，本寮法老始 めたのである。 
当初はV C $100 \mathrm{mg}$ を概ね隔日に皮下注射したが，それ でも注射回数 $1 \sim 18$ 回, 平均 5.2 回で効果を認めた。今 回注国立弘前病院の德永医長の「アレルギー性皮膚疾患 に対するビタミンC大量静注療法」という報告に刺戟さ れて，再びこの実験を行ったのであるが，上記の如き成 績をあげて，らい性結節性紅斑の治療に用いうるととを 再確認した。ことに上記症例 8 の如く, 現在本疾患に最 有効とされているコーチゾン療法が幻覚, 妄想などの副 作用誘発のため使用できない症例にむ, ビタミンC 療法 は何らの副作用なく用いうるととは, らいの臨林医にと って甚だ有利であると思う。

因みにビタミンC剂の作用機序については，コリンエ ステラーゼ活性值の上昇および肝機能の改善による解毒 ないし抗アレルギー作用とか血液内ビタミンC 值低下の 改善とか抗ヒスタミン作用とかと説明されているが, 著 者が最初に用いた時の考想は, 熱性疾患時のビタミンC 減少の補給の意味であった。その後コーチゾン系薬剤が この紅斑に有効なととが広く認められるに至り, 副腎皮 質ホルモンの関係が考慮されるが，著者はこの紅斑が単 なるッ反応実施や種痘にても誘発されることのある経験 と, ハイポンの如き還元剂の注射が有効なととや，ビタ ミンCの還元能などから, 蛋白性分解産物の本紅斑誘発 作用をビタミン Cの還元能が抑制するためではなかろう かと推定する。

\section{結語}

1. 著者らはらい性結節性紅斑の治療に, ビタミンC大 量静注寮法在行い, 有効率 $72.7 \%(8 / 11)$ の結果をえ
た。

2. ビタミンCはビタミン「タケダ」の1cc(1-アスコル ビン酸 $100 \mathrm{mg}$ 含有) と2cc (同じく500mg含有) とを用 い, 毎日 1 回静注し連用した。

3. 紅斑退色までの平均娔用日数は 4 日（最長 6 日, 最 短 2 日）であった。

4. 紅斑吸収消失までの平均使用日数は10日（最長15日 最短 4 日) であった。

5. 解熱は渙散性, ときには分利性で紅斑の退色と平行 した。

6. 精神分裂病的傾向の患者で, コーチゾンによって幻 覚，妄想を来し，本紅斑に対し無効であった 1 例に， この療法を行って顕著な効果充えた。

7. 副作用は何屯認められない。

\section{文献}

1. Ugarriza, R.G. : 癞性敗血症之 Cebion Arch. f. Schiffs u. Trop.-Hyg. Vol. 43, No.1 (1939)

[Intern. J1. Leprosy Vol. 8, No.2 (1940) に抄録〕

2. 橓蔂俊雄: 瀨性綰節性江斑のビタミンC療法, レプ ラ , 12-1 (1941) 114

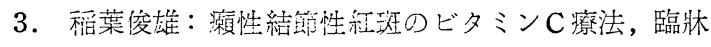
医報，14-50(1942）4

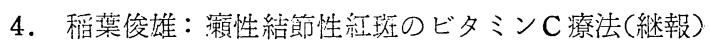
レプラ , 14-2 (1943) 175

5. 徳永栄一：アレルギ一性皮膚疾患に対するビタミン C大量静注療法, 実験治療No.318 昭和33年(1958) 